\title{
Total Synthesis of Altissimacoumarin D, a Small Molecule Sirtuin1 Activator
}

\author{
Anna C. Silva, ${ }^{a}$ Hanae Benelkebir, ${ }^{b}$ Rosangela S. C. Lopes, ${ }^{a}$ Claudio C. Lopes ${ }^{a}$ and \\ A. Ganesan*,b \\ ${ }^{a}$ Departamento de Química Analítica, Instituto de Química, \\ Universidade Federal do Rio de Janeiro, CT, Bloco A, 508, 21949-900 Rio de Janeiro-RJ, Brazil \\ ${ }^{b}$ School of Pharmacy, University of East Anglia, Norwich Research Park, NR4 7TJ, Norwich, \\ United Kingdom
}

\begin{abstract}
The total synthesis of the plant natural product altissimacoumarin D was achieved by the Mitsunobu alkylation of isofraxidin by geraniol. Isofraxidin was prepared from 2,4-dihydroxybenzaldehyde in five steps. The key reaction was the Knoevenagel condensation of an ortho-hydroxybenzaldehyde with Meldrum's acid under neutral conditions in water and one-pot acid catalyzed cyclization to the coumarin.
\end{abstract}

Keywords: natural products, epigenetics, sirtuins, coumarins

\section{Introduction}

Historically, natural products are a rich source of biologically active compounds including many of our current therapeutic agents..$^{1-5}$ In the present day, natural products continue to play a significant role in the development of small molecule chemical probes for the new science of epigenetics. ${ }^{6}$ Numerous natural products that inhibit specific epigenetic enzyme-catalyzed structural modifications of nucleic acids and histone proteins are known, such as laccaic acid (targeting deoxyribonucleic acid (DNA) methyltransferase), ${ }^{7}$ anacardic acid (targeting histone acetyltransferase), ${ }^{8}$ trichostatin A (targeting histone deacetylase), ${ }^{9}$ nauhoic acid (targeting lysine methyltransferase) ${ }^{10}$ and tripartin (targeting lysine demethylase). ${ }^{11}$ The depsipeptide romidepsin, a histone deacetylase inhibitor of bacterial origin, is a particularly impressive case as it has progressed from discovery to an approved epigenetic drug for the treatment of T-cell lymphoma. ${ }^{12,13}$

The zinc-dependent histone deacetylases (HDACs) are enzymes that hydrolyze acyl-lysine (chiefly acetyl-lysine) residues in proteins and revert them to native lysine, usually with a gene silencing effect as a consequence. ${ }^{14}$ An additional class of sirtuin histone deacylases catalyze the same reaction through an entirely different nicotinamide adenine

*e-mail: a.ganesan@uea.ac.uk

This paper is part of the PubliSBQ Special Issue "IUPAC-2017" (http://publi.sbq.org.br/). dinucleotide $\left(\mathrm{NAD}^{+}\right)$-dependent catalytic mechanism. The seven human sirtuins, Sirt1-7, are implicated in a number of disease conditions and there is much interest in both activators and inhibitors of sirtuin enzymes. ${ }^{15}$ Although some dietary natural products such as resveratrol, quercetin or epigallocatechin gallate are reported as sirtuin modulators, their promiscuous nature is non-ideal for use as chemical probes and more selective molecules are needed. A recent lead from natural product screening comes from Ailanthus altissima (the tree of heaven), a plant used in Chinese and Korean traditional medicine. From the bark extract, four coumarins were identified that are Sirt1 activators (Figure 1).$^{16}$ At a concentration of $10 \mu \mathrm{M}$, the most active compound altissimacoumarin D significantly increased Sirt1 catalyzed deacetylation of a p53 peptide Sirt1 substrate in vitro and decreased the transcriptional activity of p53 in a cell-based reporter assay.

Due to the interesting biological activity, we embarked on the total synthesis of altissimacoumarin D. Our biogenetic retrosynthesis (Figure 2) assumed that the likely origin of altissimacoumarin D (1) is through the geranylation of another coumarin natural product, isofraxidin (2). There are several total syntheses of isofraxidin in the literature, by Spath and Jerzmanowska-Sienkiewiczowa, ${ }^{17}$ Spath and Dobrovolny, ${ }^{18}$ Rouessac and Leclerc, ${ }^{19} \mathrm{Chen}^{20}$ and Gao et al..$^{21}$ from which we selected the Chen route as the starting point for our studies due to its concise and simple nature. In Chen's four step synthesis, isofraxidin arose 
<smiles>COc1cc2ccc(=O)oc2c(OC)c1OCC(O)[C@](C)(O)CCC=C(C)C</smiles>

altissimacoumarin $\mathrm{C}$<smiles>COc1cc2ccc(=O)oc2c(OC)c1OCC(O)[C@](C)(O)CCC1OC1(C)C</smiles>

altissimacoumarin $\mathrm{E}$<smiles>COc1cc2ccc(=O)oc2c(OC)c1OCC=C(C)CCC=C(C)C</smiles>

altissimacoumarin D<smiles>COc1cc2ccc(=O)oc2c(OC)c1OC[C@@H](O)[C@H](C)[C@H]1OC1C=C(C)C</smiles>

altissimacoumarin $\mathrm{F}$

Figure 1. The structures of altissimacoumarin Sirt1 activators.

from the formation of a coumarin from an $o$-hydroxy benzaldehyde derivative, which is in turn prepared by the functionalization of resorcinol. Nevertheless, we have substantially altered the reaction conditions for the Knoevenagel reaction and subsequent coumarin cyclization compared to the published procedure.

\section{Results and Discussion}

Our synthesis began with the halogenation of commercially available 2,4-dihydroxybenzaldehyde (3, Scheme 1) to give the dibrominated derivative 4. Halogen displacement under van Koten's conditions with copper(I) chloride and sodium methoxide afforded 2,4-dihydroxy-3,5-dimethoxybenzaldehyde (5) in good yield. ${ }^{22}$ At this stage, Chen's Knoevenagel condensation with diethyl malonate was attempted but resulted in poor yields. Furthermore, the lack of experimental detail made an effective reproduction difficult. The method used in Rouessac's synthesis, ${ }^{19}$ whereby a trimethoxylated benzaldehyde was condensed with Meldrum's acid and zinc oxide, was also unsatisfactory when applied to our aldehyde 5. After investigating alternative reaction<smiles>COc1cc2ccc(=O)oc2c(OC)c1OCC=C(C)CCC=C(C)C</smiles>

1 , altissimacoumarin $D$ conditions, we achieved a high yield of the Knoevenagel adduct 6 with Bigi's procedure. ${ }^{23}$ This mild protocol with Meldrum's acid in the absence of extraneous acid or base catalysis has the benefit of being environmentally green as it is conducted in water without organic co-solvents. While intermediate 6 was cyclized to coumarin 7 in $90 \%$ yield under acid catalysis, we discovered that telescoping the Knoevenagel condensation and cyclization in a onepot operation from aldehyde $\mathbf{5}$ to coumarin $\mathbf{7}$ was more efficient. The final step in the isofraxidin synthesis was the coumarin decarboxylation, for which our best yields were obtained by refluxing 7 in pyridine and ethylene glycol. ${ }^{24}$

With isofraxidin in hand through a five step sequence ( $58 \%$ overall yield), we introduced the geranyl sidechain. Under Mitsunobu conditions at room temperature, the reaction between isofraxidin and geraniol (Scheme 2) provided altissimacoumarin D (1). Although the reaction proceeded in a modest $54 \%$ yield, there was no attempt at optimization as we obtained a sufficient quantity (100 mg) of the natural product for biological studies. Our synthetic material had an excellent match with the ${ }^{1} \mathrm{H}$ and ${ }^{13} \mathrm{C}$ nuclear magnetic resonance (NMR) spectroscopic data reported for the natural product (Table 1).<smiles>C=C</smiles><smiles>COc1cc2ccc(=O)oc2c(OC)c1O</smiles>

2, isofraxidin<smiles>C=CCc1cc(OC)c(O)c(OC)c1O</smiles>

o-hydroxy aldehyde

Figure 2. Retrosynthesis of altissimacoumarin D (1) from resorcinol. 
<smiles>O=Cc1ccc(O)cc1O</smiles>

3<smiles>O=Cc1cc(Br)c(O)c(Br)c1O</smiles>

4<smiles>COc1cc(C=O)c(O)c(OC)c1O</smiles>

5<smiles>COc1cc2ccc(=O)oc2c(OC)c1O</smiles>

2, isofraxidin<smiles>COc1cc2cc(C(=O)O)c(=O)oc2c(OC)c1O</smiles>

7

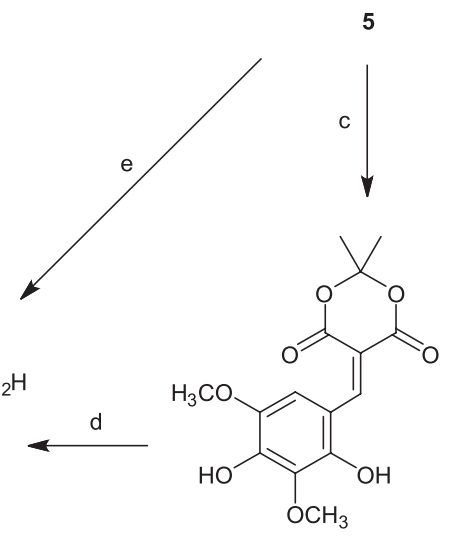

6

Scheme 1. (a) $\mathrm{Br}_{2}$, EtOH, 30 min (98\%); (b) $\mathrm{NaOMe}, \mathrm{CuCl}$, MeOH/DMF, reflux, 4 h (70\%); (c) Meldrum's acid, $\mathrm{H}_{2} \mathrm{O}, 80{ }^{\circ} \mathrm{C}, 2 \mathrm{~h},\left(94 \%\right.$ ); (d) $\mathrm{H}_{2} \mathrm{SO}_{4}$, $90 \mathrm{~min}$ (90\%); (e) one-pot combination of (c) and (d) (90\%); (f) Py, ethylene glycol, reflux, $3.5 \mathrm{~h}(94 \%)$.<smiles>COc1cc2ccc(=O)oc2c(OC)c1OC/C=C(\C)CCC=C(C)C</smiles>

1, altissimacoumarin D

Scheme 2. (a) Geraniol, $\mathrm{Ph}_{3} \mathrm{P}$, diisopropyl azodicarboxylate (DIAD), tetrahydrofuran (THF), $24 \mathrm{~h}$ (54\%).

Table 1. Comparison of altissimacoumarin $\mathrm{D}^{1} \mathrm{H}$ and ${ }^{13} \mathrm{C}$ NMR chemical shifts between the naturally isolated material and the synthetic sample

\begin{tabular}{lccc}
\hline$\delta_{\mathrm{H}}$, natural product & $\delta_{\mathrm{H}}$, synthetic sample & $\begin{array}{c}\delta_{\mathrm{C}} \text {, natural } \\
\text { product }\end{array}$ & $\begin{array}{c}\delta_{\mathrm{C}} \text {, synthetic } \\
\text { sample }\end{array}$ \\
\hline $1.59(\mathrm{~s})$ & $1.52(\mathrm{~s})$ & 16.4 & 16.4 \\
$1.67(\mathrm{~s})$ & $1.60(\mathrm{~s})$ & 17.6 & 17.6 \\
$1.69(\mathrm{~s})$ & $1.63(\mathrm{~s})$ & 25.6 & 25.6 \\
$2.05,2.08(\mathrm{~m})$ & $1.99(\mathrm{~m})$ & 26.3 & 26.3 \\
$3.89(\mathrm{~s})$ & $3.82(\mathrm{~s})$ & 39.6 & 39.6 \\
$4.03(\mathrm{~s})$ & $3.96(\mathrm{~s})$ & 56.3 & 56.2 \\
$4.68(\mathrm{~d}, J 7 \mathrm{~Hz})$ & $4.62(\mathrm{~d}, J 7 \mathrm{~Hz})$ & 61.7 & 61.7 \\
$5.06(\mathrm{t}, J 7 \mathrm{~Hz})$ & $5.00(\mathrm{t}, J 8 \mathrm{~Hz})$ & 70.3 & 70.2 \\
$5.56(\mathrm{t}, J 7 \mathrm{~Hz})$ & $5.49(\mathrm{t}, J 8 \mathrm{~Hz})$ & 103.5 & 103.5 \\
$6.34(\mathrm{~d}, J 10 \mathrm{~Hz})$ & $6.28(\mathrm{~d}, J 8 \mathrm{~Hz})$ & 114.4 & 114.4 \\
$6.66(\mathrm{~s})$ & $6.58(\mathrm{~s})$ & 115.1 & 115.1 \\
$7.61(\mathrm{~d}, J 10 \mathrm{~Hz})$ & $7.54(\mathrm{~d}, J 12 \mathrm{~Hz})$ & 119.6 & 119.6 \\
& & 123.8 & 123.8 \\
& & 131.7 & 131.7 \\
& & 141.8 & 141.8 \\
& & 142.5 & 142.5 \\
& & 142.9 & 143.0 \\
& & 143.5 & 143.4 \\
& & 144.9 & 144.9 \\
& & 150.7 & 150.7 \\
& & 160.6 & 160.5 \\
\hline
\end{tabular}

\section{Conclusions}

In summary, we report the total synthesis of the Sirt1 activator altissimacoumarin D in six steps from 2,4-dihydroxybenzaldehyde. A noteworthy feature is the new high-yielding route towards the intermediary isofraxidin via Knoevenagel condensation in water followed by cyclization to the coumarin carboxylic acid 7 in one-pot. Thermal decomposition of the pyridinium salt of 7 effected decarboxylation to give isofraxidin in high yield, after which geranylation afforded altissimacoumarin D. The ready access to altissimacoumarin D will facilitate its use as a starting material for the synthesis of the more heavily oxygenated natural products in this family, while the modular route facilitates the synthesis of analogues for structure-activity relationship studies.

\section{Experimental}

2,4-Dihydroxybenzaldehyde was obtained commercially (Sigma-Aldrich Co., St. Louis, MO, USA) and used without further purification. All reactions involving a dry atmosphere were performed with a slight positive pressure of argon. Analytical thin-layer chromatography 
was done on $0.25 \mathrm{~mm}$ silica gel $60 \mathrm{~F} 254$ plates, and compounds visualized using UV irradiation or $\mathrm{KMnO}_{4}$. Flash chromatography was carried out on columns packed with silica gel 60 (0.040-0.063 mm particle sizes). Nuclear magnetic resonance (NMR) spectra were obtained on a Bruker Avance-III spectrometer. The splitting patterns are reported as s (singlet), d (doublet), t (triplet), q (quartet), and $\mathrm{m}$ (multiplet).

\section{3,5-Dibromo-2,4-dihydroxybenzaldehyde (4, CAS 116096-91-4)}

To a stirred solution of 2,4-dihydroxybenzaldehyde $(2.8 \mathrm{~g}, 20 \mathrm{mmol})$ in ethanol $(40 \mathrm{~mL})$ was added bromine $(6.4 \mathrm{~g}, 40 \mathrm{mmol})$ dropwise at room temperature. After stirring for $30 \mathrm{~min}$ the reaction mixture was poured into distilled water $(100 \mathrm{~mL})$ and filtered. The filtrate was washed with water and the residual bromine present in the aqueous phase was quenched with a saturated solution of sodium thiosulfate. Compound $\mathbf{4}$ was obtained as a white powder $(5.9 \mathrm{~g}, 98 \%)$, and the physical and spectroscopic data are in accordance with those previously reported. ${ }^{25}$ mp 188-189 ${ }^{\circ} \mathrm{C}\left(\right.$ Lit. $\left.^{25} \mathrm{mp} 200{ }^{\circ} \mathrm{C}\right) ;{ }^{1} \mathrm{H}$ NMR $(400 \mathrm{MHz}$, methanol- $\left.d_{4}\right) \delta 7.88(\mathrm{~s}, 1 \mathrm{H}), 9.71(\mathrm{~s}, 1 \mathrm{H}) ;{ }^{13} \mathrm{C} \mathrm{NMR}$ $\left(100 \mathrm{MHz}\right.$, methanol- $\left.d_{4}\right) \delta 103.1,119.9,132.0,138.5$, 154.1, 154.7, 196.2.

\section{2,4-Dihydroxy-3,5-dimethoxybenzaldehyde (5, CAS 182427-46-9)}

To a stirred solution of $4(11.8 \mathrm{~g}, 40 \mathrm{mmol})$ in a 2:5 solution of anhydrous methanol in anhydrous dimethylformamide $(70 \mathrm{~mL})$ was added $\mathrm{CuCl}(0.5 \mathrm{~g}$, $5 \mathrm{mmol})$ and $\mathrm{NaOMe}(21.6 \mathrm{~g}, 400 \mathrm{mmol})$. The reaction mixture was heated under reflux at $100{ }^{\circ} \mathrm{C}$ for $4 \mathrm{~h}$. The solvent was then evaporated in vacuo, distilled water $(50 \mathrm{~mL})$ was added and the $\mathrm{pH}$ adjusted to 2 using concentrated $\mathrm{HCl}$. After 15 min the reaction mixture was transferred into a separation funnel and the product extracted using chloroform $(5 \times 20 \mathrm{~mL})$. The organic layer was washed with brine, dried with $\mathrm{MgSO}_{4}$, filtered and the solvent evaporated in vacuo. Compound $\mathbf{5}$ was obtained as a brown solid (5.5 g, 70\%), and the physical and spectroscopic data are in accordance with those previously reported. $.^{21} \mathrm{mp} 88-89^{\circ} \mathrm{C}$ (Lit. $\left.{ }^{21} \mathrm{mp} 87.5-89.8{ }^{\circ} \mathrm{C}\right) ;{ }^{1} \mathrm{H}$ NMR $\left(400 \mathrm{MHz}, \mathrm{DMSO}-d_{6}\right) \delta 3.86(\mathrm{~s}, 6 \mathrm{H}), 7.29(\mathrm{~s}, 1 \mathrm{H}), 8.68$ $(\mathrm{s}, 1 \mathrm{H}) ;{ }^{13} \mathrm{C} \mathrm{NMR}\left(100 \mathrm{MHz}, \mathrm{CDCl}_{3}\right) \delta 56.6,60.9,109.0$, 112.9, 134.6, 141.3, 147.1, 151.7, 194.6.

\section{5-(2,4-Dihydroxy-3,5-dimethoxybenzylidene)-2,2-dimethyl-} 1,3-dioxane-4,6-dione (6)

Meldrum's acid $(0.16 \mathrm{~g}, 1 \mathrm{mmol})$ was added to a stirred solution of aldehyde $\mathbf{5}(0.210 \mathrm{~g}, 1 \mathrm{mmol})$ in $2 \mathrm{~mL}$ of water at $80{ }^{\circ} \mathrm{C}$ and the reaction mixture left for $2 \mathrm{~h}$ to the point where a precipitate was formed. The solid was filtered and dried to give compound 6 as a white solid $(0.323 \mathrm{~g}, 94 \%)$. mp $259-261{ }^{\circ} \mathrm{C}$; ${ }^{1} \mathrm{H}$ NMR $\left(400 \mathrm{MHz}, \mathrm{MeOD}-d_{1}\right) \delta 2.05$ (s, 6H), $3.85(\mathrm{~s}, 3 \mathrm{H}), 3.88(\mathrm{~s}, 3 \mathrm{H}), 7.05(\mathrm{~s}, 1 \mathrm{H}), 8.70(\mathrm{~s}$, $1 \mathrm{H}) ;{ }^{13} \mathrm{C}$ NMR (100 MHz, MeOD- $\left.d_{1}\right) \delta 56.2,60.8,105.8$, $109.5,112.8,134.2,144.7,145.9,146.9,149.6,157.5$, 164.2 (some carbon signals are coincident).

7-Hydroxy-6,8-dimethoxy-2-oxo-2H-chromene-3-carboxylic acid (7, CAS 149143-82-8)

Meldrum's acid $(0.16 \mathrm{~g}, 1 \mathrm{mmol})$ was added to a stirred solution of aldehyde $5(0.210 \mathrm{~g}, 1 \mathrm{mmol})$ in $2 \mathrm{~mL}$ of water at $80^{\circ} \mathrm{C}$. After two hours, the reaction mixture was cooled and acidified at $0{ }^{\circ} \mathrm{C}$ to $\mathrm{pH} 1$ with concentrated sulfuric acid. After stirring for $1.5 \mathrm{~h}$, the solution was poured onto crushed ice and warmed to room temperature. The crystals were filtered, washed with water, and dried to give coumarin 7 as white crystals $(0.25 \mathrm{~g}, 90 \%)$, and the physical and spectroscopic data are in accordance with those previously reported. ${ }^{19} \mathrm{mp} 227-228{ }^{\circ} \mathrm{C}$ (Lit. ${ }^{19} \mathrm{mp}$ $227-228{ }^{\circ} \mathrm{C}$ ); ${ }^{1} \mathrm{H}$ NMR $\left(400 \mathrm{MHz}\right.$, DMSO- $\left.d_{6}\right) \delta 3.84$ (s, $6 \mathrm{H}), 4.63$ (br s, 2H), $7.26(\mathrm{~s}, 1 \mathrm{H}), 8.66(\mathrm{~s}, 1 \mathrm{H}) ;{ }^{13} \mathrm{C} \mathrm{NMR}$ $\left(100 \mathrm{MHz}, \mathrm{DMSO}-d_{6}\right) \delta 56.2,60.8,105.9,109.5,112.8$, 134.2, 144.7, 145.9, 146.9, 149.6, 157.5, 164.2.

7-Hydroxy-6,8-dimethoxy-2H-chromen-2-one (2, isofraxidin, CAS 486-21-5)

Coumarin 7 ( $0.32 \mathrm{~g}, 1.4 \mathrm{mmol})$ was refluxed for $3.5 \mathrm{~h}$ in a solution of pyridine/ethylene glycol $(1.35 \mathrm{~mL} / 1.21 \mathrm{~mL})$. The solution was cooled, acidified with $2 \mathrm{M} \mathrm{HCl}$ and extracted with dichloromethane. Solvent evaporation afforded isofraxidin (2) as white crystals (0.25 g, 94\%), and the physical and spectroscopic data are in accordance with those previously reported. $.^{19} \mathrm{mp} 148-149{ }^{\circ} \mathrm{C}$ (Lit. ${ }^{19}$ mp $\left.144^{\circ} \mathrm{C}\right) ;{ }^{1} \mathrm{H}$ NMR $\left(400 \mathrm{MHz}, \mathrm{CDCl}_{3}\right) \delta 3.86(\mathrm{~s}, 3 \mathrm{H})$, $4.01(\mathrm{~s}, 3 \mathrm{H}), 6.21(\mathrm{~d}, J 9.0 \mathrm{~Hz}, 1 \mathrm{H}), 6.59(\mathrm{~s}, 1 \mathrm{H}), 7.54(\mathrm{~d}$, $J 9.0 \mathrm{~Hz}, 1 \mathrm{H}) ;{ }^{13} \mathrm{C}$ NMR $\left(100 \mathrm{MHz}\right.$, DMSO- $\left.d_{6}\right) \delta 56.2$, $60.8,105.9,109.5,112.8,134.2,144.5,145.9,146.9$, $149.6,164.2$.

\section{Altissimacoumarin D (1, CAS 1388627-67-5)}

To a stirring solution of isofraxidin $(0.110 \mathrm{~g}, 0.31 \mathrm{mmol})$ in anhydrous tetrahydrofuran (THF, $1.0 \mathrm{~mL}$ ) was added triphenylphosphine $(0.081 \mathrm{~g}, 0.31 \mathrm{mmol})$ and geraniol (0.05 mL, $0.29 \mathrm{mmol})$. DIAD (0.05 g, $0.25 \mathrm{mmol})$ in THF $(0.5 \mathrm{~mL})$ was added dropwise and the reaction mixture left stirring for 24 hours. The solvent was removed and the crude product purified by preparative thin layer chromatography with an eluent of $6 \% \mathrm{MeOH} / \mathrm{CH}_{2} \mathrm{Cl}_{2}$. The product was extracted from the silica with a solution 
of $10 \% \mathrm{MeOH} / \mathrm{CH}_{2} \mathrm{Cl}_{2}$, filtered and the solvent evaporated in vacuo to afford altissimacoumarin $\mathrm{D}$ as a colourless solid (0.10 g, 54\%); mp 225-226 ${ }^{\circ} \mathrm{C} ;{ }^{1} \mathrm{H}$ NMR $(400 \mathrm{MHz}$, $\left.\mathrm{CDCl}_{3}\right) \delta 1.52(\mathrm{~s}, 3 \mathrm{H}), 1.60(\mathrm{~s}, 3 \mathrm{H}), 1.63(\mathrm{~s}, 3 \mathrm{H}), 1.99(\mathrm{~m}$, $4 \mathrm{H}), 3.82(\mathrm{~s}, 3 \mathrm{H}), 3.96(\mathrm{~s}, 3 \mathrm{H}), 4.62(\mathrm{~d}, J 7 \mathrm{~Hz}, 2 \mathrm{H}), 5.00$ $(\mathrm{t}, J 8 \mathrm{~Hz}, 1 \mathrm{H}), 5.49(\mathrm{t}, J 8 \mathrm{~Hz}, 1 \mathrm{H}), 6.28(\mathrm{~d}, J 8 \mathrm{~Hz}, 1 \mathrm{H})$, $6.58(\mathrm{~s}, 1 \mathrm{H}), 7.54(\mathrm{~d}, J 12 \mathrm{~Hz}) ;{ }^{13} \mathrm{C} \mathrm{NMR}\left(100 \mathrm{MHz}, \mathrm{CDCl}_{3}\right)$ $\delta$ 16.4, 17.6, 25.6, 26.3, 39.6, 56.2, 61.7, 70.2, 103.5, 114.4, $115.1,119.6,123.8,131.7,141.8,142.5,143.0,143.4$, $144.9,150.7,160.5$.

\section{Supplementary Information}

Supplementary information ( ${ }^{1} \mathrm{H}$ and ${ }^{13} \mathrm{C}$ NMR spectra) is available free of charge at http://jbcs.org.br as a PDF file.

\section{Acknowledgments}

We thank the Brazilian Science without Borders program at CNPq-UFRJ for a scholarship to Anna C. Silva and the COST Action TD0905 Epigenetics: From Bench to Bedside for financial assistance.

\section{References}

1. Ganesan, A.; Curr. Opin. Chem. Biol. 2008, 12, 306.

2. Ganesan, A. In Natural Products and Cancer Drug Discovery; Koehn, F. E., ed.; Springer: Heidelberg, Germany, 2012, ch. 1.

3. Cragg, G. M.; Newman, D. J.; J. Nat. Prod. 2016, 79, 629.

4. Partridge, E.; Gareiss, P.; Kinch, M. S.; Hoyer, D.; Drug Discovery Today 2016, 21, 204.

5. Pye, C. R.; Bertin, M. J.; Lokey, R. S.; Gerwick, W. H.; Linington, R. G.; Proc. Natl. Acad. Sci. U. S. A. 2017, 114, 5601.

6. Hau, M.; Zenk, F.; Ganesan, A.; Iovino, N.; Jung, M.; Epigenetics 2017, 5, 308.

7. Fagan, R. L.; Cryderman, D. E.; Kopelovich, L.; Wallrath, L. L.; Brenner, C.; J. Biol. Chem. 2013, 288, 23858.

8. Balasubramanyam, K.; Swaminathan, V.; Ranganathan, A.; Kundu, T. K.; J. Biol. Chem. 2003, 278, 19134.
9. Yoshida, M.; Kijima, M.; Akita, M.; Beppu, T.; J. Biol. Chem. 1990, 265, 17174.

10. Williams, D. E.; Dalisay, D. S.; Li, F.; Amphlett, J.; Maneerat, W.; Chavez, M. A.; Wang, Y. A.; Matainaho, T.; Yu, W.; Brown, P. J.; Arrowsmith, C. H.; Vedadi, M.; Andersen, R. J.; Org. Lett. 2013, 15, 414.

11. Kim, S. H.; Kwon, S. H.; Park, S. H.; Lee, J. K.; Bang, H. S.; Nam, S. J.; Kwon, H. C.; Shin, J.; Oh, D. C.; Org. Lett. 2013, 15, 1834.

12. Wen, S.; Packham, G.; Ganesan, A.; J. Org. Chem. 2008, 73, 9353.

13. Ganesan, A. In Successful Drug Discovery, vol. 2; Fischer, J.; Childers, W. E., eds.; Wiley: Weinheim, Germany, 2016, ch. 2.

14. Zwergel, C.; Stazi, G.; Valente, S.; Mai, A.; J. Clin. Epigenet. 2016, $2,1$.

15. Schiedel, M.; Robaa, D.; Rumpf, T.; Sippl, W.; Jung, M.; Med. Res. Rev. 2018, 38, 147.

16. Dao, T. T.; Tran, T. L.; Kim, J.; Nguyen, P. H.; Lee, E. H.; Park, J.; Jang, I. S.; Oh, W. K.; J. Nat. Prod. 2012, 75, 1332.

17. Spath, E.; Jerzmanowska-Sienkiewiczowa, Z.; Chem. Ber. 1937, $70 B, 1672$.

18. Spath, E.; Dobrovolny, E.; Chem. Ber. 1938, 71B, 1831.

19. Rouessac, F.; Leclerc, A.; Synth. Commun. 1993, 23, 1147.

20. Chen, W. M.; Indian J. Chem., Sect. B: Org. Chem. Incl. Med. Chem. 1996, 35B, 1085.

21. Gao,W.; Li, Q.; Chen, J.; Wang, Z.; Hua, C.; Molecules 2013, 18, 15613.

22. Aalten, H. L.; van Koten, G.; Grove, D. M.; Kuilman, T.; Piekstra, O. G.; Hulshof, L. A.; Sheldon, R. A.; Tetrahedron 1989, 45, 5565.

23. Bigi, F.; Carloni, S.; Ferrari, L.; Maggi, R.; Mazzacani, A.; Sartori, G.; Tetrahedron Lett. 2001, 42, 5203.

24. Cai, X.; Yang, J.; Zhou, J.; Lu, W.; Hu, C.; Gu, Z.; Huo, J.; Wang, X.; Cao, P.; Bioorg. Med. Chem. 2013, 21, 84.

25. Gagey, N.; Neveu, P.; Benbrahim, C.; Goetz, B.; Aujard, I.; Baudin, J.-B.; Jullien, L.; J. Am. Chem. Soc. 2007, 129, 9986.

Submitted: August 18, 2017

Published online: February 9, 2018 